\title{
High Diversity of Leptospira Species Infecting Bats Captured in the Urabá Region (Antioquia-Colombia)
}

\author{
Fernando P. Monroy ${ }^{1, *(1)}$, Sergio Solari ${ }^{2}$, Juan Álvaro Lopez ${ }^{3}$, Piedad Agudelo-Flórez ${ }^{4}$ \\ and Ronald Guillermo Peláez Sánchez ${ }^{4}$ \\ 1 Department of Biological Sciences, Northern Arizona University, Flagstaff, AZ 86011, USA \\ 2 Institute of Biology, University of Antioquia, Medellín 50010, Colombia; sergio.solari@udea.edu.co \\ 3 Microbiology School, Primary Immunodeficiencies Group, University of Antioquia, \\ Medellín 50010, Colombia; alvaro.lopez@udea.edu.co \\ 4 Basic Science Research Group, Graduate School—CES University, Medellín 50021, Colombia; \\ pagudelo@ces.edu.co (P.A.-F.); rpelaezp@ces.edu.co (R.G.P.S.) \\ * Correspondence: Fernando.Monroy@nau.edu; Tel.: +1-928-523-0042
}

check for updates

Citation: Monroy, F.P.; Solari, S.; Lopez, J.Á.; Agudelo-Flórez, P.; Peláez Sánchez, R.G. High Diversity of Leptospira Species Infecting Bats Captured in the Urabá Region (Antioquia-Colombia). Microorganisms 2021, 9, 1897. https://doi.org/10.3390/ microorganisms 9091897

Academic Editor: Javier Millán

Received: 24 August 2021

Accepted: 4 September 2021

Published: 7 September 2021

Publisher's Note: MDPI stays neutral with regard to jurisdictional claims in published maps and institutional affiliations.

Copyright: (c) 2021 by the authors. Licensee MDPI, Basel, Switzerland. This article is an open access article distributed under the terms and conditions of the Creative Commons Attribution (CC BY) license (https:/ / creativecommons.org/licenses/by/ $4.0 /)$.

\begin{abstract}
Leptospirosis is a globally distributed zoonotic disease caused by pathogenic bacteria of the genus Leptospira. This zoonotic disease affects humans, domestic animals and wild animals. Colombia is considered an endemic country for leptospirosis; Antioquia is the second department in Colombia, with the highest number of reported leptospirosis cases. Currently, many studies report bats as reservoirs of Leptospira spp. but the prevalence in these mammals is unknown. The goal of this study was to better understand the role of bats as reservoir hosts of Leptospira species and to evaluate the genetic diversity of circulating Leptospira species in Antioquia-Colombia. We captured 206 bats in the municipalities of Chigorodó (43 bats), Carepa (43 bats), Apartadó (39 bats), Turbo (40 bats), and Necoclí (41 bats) in the Urabá region (Antioquia-Colombia). Twenty bats tested positive for Leptospira spp. infection (20/206-9.70\%) and the species of infected bats were Carollia perspicillata, Dermanura rava, Glossophaga soricina, Molossus molossus, Artibeus planirostris, and Uroderma convexum. These species have different feeding strategies such as frugivorous, insectivores, and nectarivores. The infecting Leptospira species identified were Leptospira borgpetersenii (3/20-15\%), Leptospira alexanderi (2/20-10\%), Leptospira noguchii (6/20-30\%), Leptospira interrogans (3/20-15\%), and Leptospira kirschneri $(6 / 20-30 \%)$. Our results showed the importance of bats in the epidemiology, ecology, and evolution of Leptospira in this host-pathogen association. This is the first step in deciphering the role played by bats in the epidemiology of human leptospirosis in the endemic region of Urabá (Antioquia-Colombia).
\end{abstract}

Keywords: Leptospira; bats; Colombia; leptospirosis; species; type; 16S ribosomal gene

\section{Introduction}

Leptospirosis is an emerging zoonotic disease caused by pathogenic bacteria of the genus Leptospira [1]. Previous studies have estimated that 1.03 million cases and 58,900 deaths occur due to leptospirosis worldwide annually [2]. Leptospirosis is considered a neglected disease, found mainly in the tropical regions of developing countries [3] and is now recognized as an emerging infectious disease due to large outbreaks in different regions of the world, which are associated with environmental disasters, and extreme climate change. In many endemic regions, severe forms of the disease, such as Weil's disease and pulmonary hemorrhage syndrome have emerged as the leading cause of death [4]. Currently, about 65 genomic Leptospira species have been identified (NCBI database: https: / / www.ncbi.nlm.nih.gov/genome [accessed on 30 April 2021]), which are subdivided into four main clades according to the phylogenetic analysis of 1371 conserved genes: pathogens (P1), pathogens (P2), saprophytes (S1), and saprophytes (S2) [4,5]. Through serological classification about 300 Leptospira serovars have been described, which are grouped into approximately 30 serogroups and about 200 of these serovars have been 
considered pathogenic [6]. Colombia is an endemic country for leptospirosis with at least 500 cases every year [7]. Antioquia is the second department in Colombia with the highest number of confirmed cases of leptospirosis [7], with a seroprevalence close to $12.5 \%$ [8]. Leptospira interrogans and L. santarosai have been identified as the causative agents of this disease [9]. Therefore, this department in an important region in Colombia for the study of leptospirosis.

Rodents and dogs are often identified as potential sources of human infection, but other mammals have also been identified in the transmission cycle of leptospirosis [1]. Globally, various studies have explored the biological role of bats as reservoirs of zoonotic pathogens due to their ability to fly long distances and disperse pathogens (viruses [10], bacteria [11], parasites [12] and fungi [13]) through urine, saliva, and feces. Bats are the only true flying mammals, belonging to the order Chiroptera [14]. This order includes over 1400 different species in 21 families [15], which are scattered throughout the world, except Antarctica [16]. These mammals are oriented and hunt by echolocation [17]. Depending on the species they can feed on arthropods, fruits, pollen, fish, blood, and other vertebrates (carnivores) [10]. Some species can hibernate [18], form large colonies [19], migrate long distances [20], and have long lifespans (approximately 35 years) [21].

Bats have been identified worldwide as an important reservoir of different Leptospira species (L. interrogans, L. borgpetersenii, L. kirschneri, L. fainei) and their role in disease transmission, and spillover in the life cycle of this bacterium has yet to be defined [22]. Currently, more than 50 species of infected bats with Leptospira have been reported in different countries, including Peru [23], Brazil [24], Argentina [25], Australia [26], Comoros island and Madagascar [27], Reunion Island [28], Mayotte Island [29], Indonesia [30], Malaysia [31], Tanzania [32], Trinidad [33], Sudan [34], Democratic Republic of Congo [35], Africa [36], and Azerbaijan [37]. In Colombia, two studies have reported the presence of bats naturally infected with Leptospira $[38,39]$. Due to the above characteristics, bats could act as excellent spillover of Leptospira species to the environment, favoring contamination of water and soil, serving as a direct or indirect source of infection for other animals, which are the main reservoirs and disseminators of the bacteria. The objective of the present investigation was to detect Leptospira species infecting different bat species in the Urabá region (Antioquia-Colombia) and to evaluate the genetic diversity of the circulating Leptospira species. This information will illustrate the role of bats in the transmission cycle of human leptospirosis.

\section{Materials and Methods}

\subsection{Ethical Considerations}

This research was authorized by the National Authority of Environmental Licenses of Colombia (ANLA) according to resolution 0524 of 27 May 2014, which grants permission to collect wild species of biological diversity for non-commercial scientific research purposes. This research was endorsed by the Ministry of Environment and Sustainable Development of the Republic of Colombia.

\subsection{Characteristics of the Capture Area of Specimens}

Urabá is a geographical sub-region of Colombia; its name literally means freshwater gulf, due to the low salinity of the gulf's waters, which is achieved by the mixture of seawater with large rivers flowing into the gulf. This region is surrounded by the Pacific Ocean to the west, and the Caribbean Sea to the northeast. The region is made up of eleven municipalities (Arboletes, San Juan de Urabá, San Pedro de Urabá, Necoclí, Apartado, Carepa, Chigorodó, Turbo, Mutatá, Murindó, and Vigía del Fuerte). With respect to its geographical characteristics; the disposition of its lands is of the plain type, Caribbean ecoregion, surface of $11,664 \mathrm{~km}^{2}$, average altitude of $919 \mathrm{~m}$ above sea level, 659,266 inhabitants (10.3\% of the population of the department of Antioquia), and an equatorial-type climate (https: / / www.dane.gov.co [accessed on 31 July 2021]). The research was carried out in the Urabá region (Antioquia-Colombia). The sampling took place in five different municipalities 
(Place 1-Chigorodó: $7^{\circ} 40^{\prime} 11^{\prime \prime}$ N $76^{\circ} 40^{\prime} 53^{\prime \prime}$ O), (Place 2-Carepa: $7^{\circ} 45^{\prime} 29^{\prime \prime}$ N 76 $39^{\prime} 19^{\prime \prime} \mathrm{O}$ ), (Place 3-Apartadó: $7^{\circ} 53^{\prime} 05^{\prime \prime}$ N 76 $38^{\prime} 06^{\prime \prime} \mathrm{O}$ ), (Place 4-Turbo: 8 $05^{\prime} 35^{\prime \prime}$ N 76 $43^{\prime} 42^{\prime \prime} \mathrm{O}$ ), (Place 5-Necoclí: $8^{\circ} 25^{\prime} 33^{\prime \prime} \mathrm{N} 76^{\circ} 47^{\prime} 02^{\prime \prime} \mathrm{O}$ ).

\subsection{Capture of Bats}

The bats were captured using mist nets of $2 \mathrm{~m}$ high with variable lengths of 6 and $12 \mathrm{~m}$. The nets were placed in strategic areas near fruit trees and in areas of bat traffic after night observation. The captures were made during 4 continuous nights from 5:00 pm to midnight. The traps were checked every $30 \mathrm{~min}$. Captured pregnant or lactating female bats were released immediately. These specimens were stored in cotton cloth bags until euthanasia and dissection. All captured animals were registered with a unique code. Additionally, the bat capture sites were georeferenced by GPS and the maps were generated using the environment and programming language R and packages (ggplot2, MappingGIS, sfMaps, spData, ggrepel, ggspatial, cowplot).

\subsection{Euthanasia of Captured Bats}

The euthanasia process was carried out under the guidelines of AVMA Guidelines for the Euthanasia of Animals-2020. Initially the bats were sedated with $0.1 \mathrm{~mL}$ of $2 \%$ Xylazine; euthanasia was performed using a mixture of 390 milligrams Sodium Pentobarbital and 50 milligrams Sodium Diphenyl Hydantoin. The injection was performed intramuscularly in the pectoral region with insulin syringes. Dissection and collection of organs of interest were performed and the animal's body was stored in $80 \%$ ethanol for conservation. Subsequently, bats were identified at the level of genus and species through morphological keys [40].

\subsection{DNA Extraction}

DNA extraction was performed with the commercial kit (Wizard DNA extraction kit, Promega ${ }^{\circledR}$, Madison, WI, USA) according to the manufacturer's recommendations for Gram negative bacteria.

\subsection{PCR-16S Ribosomal Gene Conditions}

Amplification of the $16 \mathrm{~S}$ ribosomal gene by PCR was performed, as described previously, by Peláez et al. (2017) [41].

\subsection{S Ribosomal Gene Sequencing from Kidneys of Bats}

The amplification products were column-purified and sent to Macrogen ${ }^{\circledR}$ Company (Seoul, Korea) for sequencing.

\subsection{Phylogenetic Analysis 165 Ribosomal Gene}

Phylogenetic analysis was performed, as described previously, by Peláez et al. (2017) [41]

\section{Results}

\subsection{Places of Bat's Capture}

The investigation was carried out in the Urabá region (Antioquia-Colombia). The sampling was undertaken in five different municipalities (Chigorodó-43 captured bats), (Carepa-43 captured bats), (Apartadó-39 captured bats), (Turbo-40 captured bats), (Necoclí-41 captured bats). In total, 206 bats were captured. The map of the Urabá region and the exact location of the three sampling sites are shown in Figure 3.3.

\subsection{Families, Genera and Species of Captured Bats}

We captured 206 bats in the five municipalities of the Urabá region (Antioquia, Colombia). These bats were classified into three different families (Phyllostomidae, Molossidae, and Vespertilionidae), 10 different genera (Artibeus, Carollia, Dermanura, Glossophaga, Sturnira, Molossus, Myotis, Uroderma, Rhogeessa, Phyllostomus), and fifteen different species 
(Artibeus jamaicensis, A. lituratus, A. planirostris, Carollia brevicauda, C. castanea, C. perspicillata, Dermanura rava, Glossophaga soricina, Sturnira bakeri, Molossus molossus, Myotis caucensis, Uroderma convexum, Phyllostomus hastatus, P. discolor), and one unidentified species belonging to the genus Rhogeessa. The genera, families and species are shown in Figure 2 . These species have different feeding habits, such as frugivorous $(60.19 \%)$, insectivores (17.47\%), omnivore $(1.45 \%)$, nectarivores $(20.87 \%)$ (Table 1$)$.

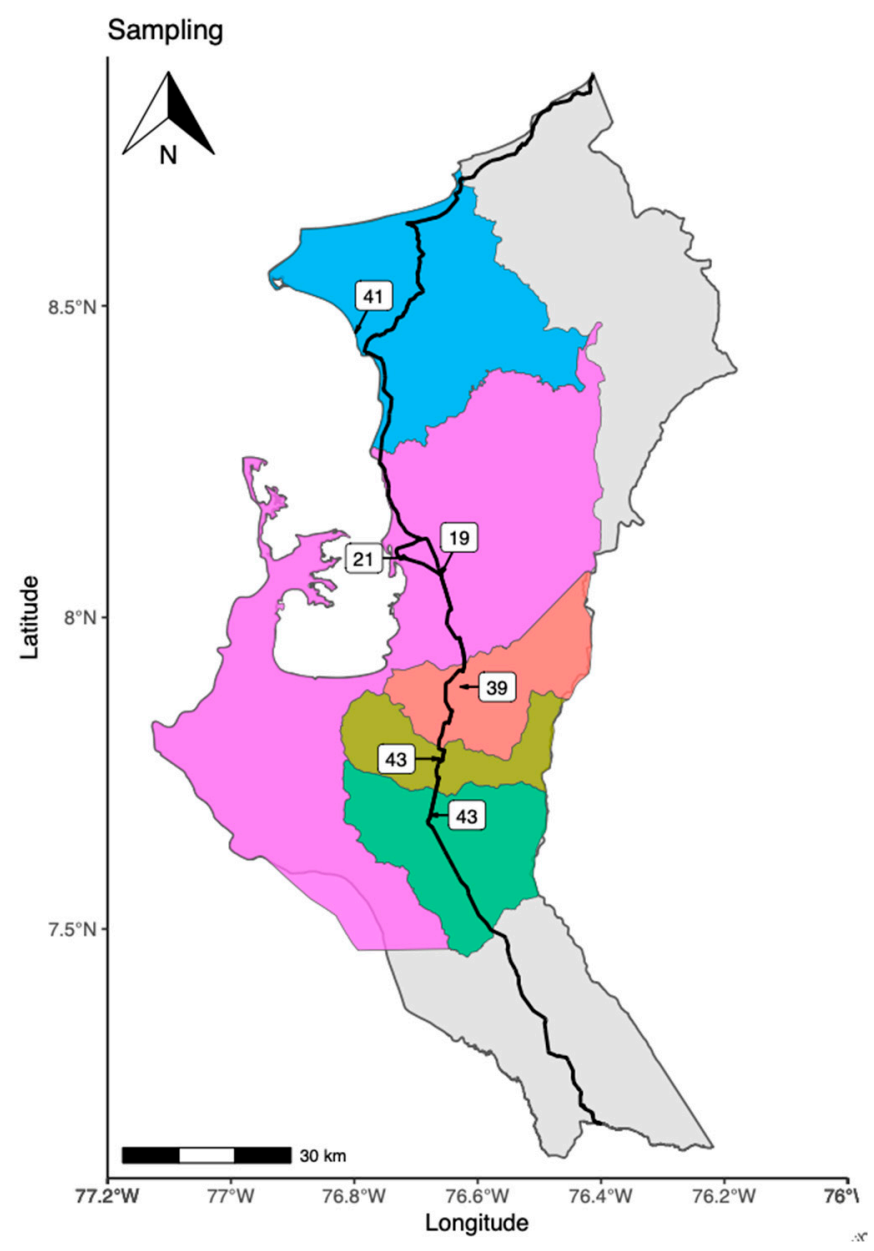

Figure 1. The geographical location of capture sites. The map shows the geographical location of the five municipalities that were used to capture the 206 bats used in this study (blue-Necoclí, purple-Turbo, orange-Apartadó, dark green-Carepa and light green-Chigorodó). These capture sites are located in the Urabá region (Antioquia-Colombia). The map was generated using the environment and programming language $\mathrm{R}$ and packages (ggplot2, MappingGIS, sfMaps, spData, ggrepel, ggspatial, cowplot).

\subsection{Detection of Leptospira spp. in Bats by Conventional PCR}

We analyzed 206 bat kidneys by PCR by amplifying the $16 \mathrm{~S}$ ribosomal gene for detection of Leptospira spp. Twenty individual bats were positive for Leptospira (20/206), obtaining a $9.7 \%$ of infected bats (Figure 3). Positive bats for Leptospira infection were found in the 5 municipalities studied (Chigorodó: 3 bats, Carepa: 2 bats, Apartadó: 3 bats, Turbo: 10 bats, and Necoclí: 2 bats). Additionally, 6 different species of bats were found to be infected: Carollia perspicillata, Dermanura rava, Glossophaga soricina, Molossus molossus, Artibeus planirostris, and Uroderma convexum. According to sex, 11 males (55\%) and 9 females (45\%) were found infected. Regarding feeding habits, 12 frugivores (60\%), 6 nectarivores $(30 \%)$, and 2 insectivores (10\%) bats were found infected (Table 2$)$. 


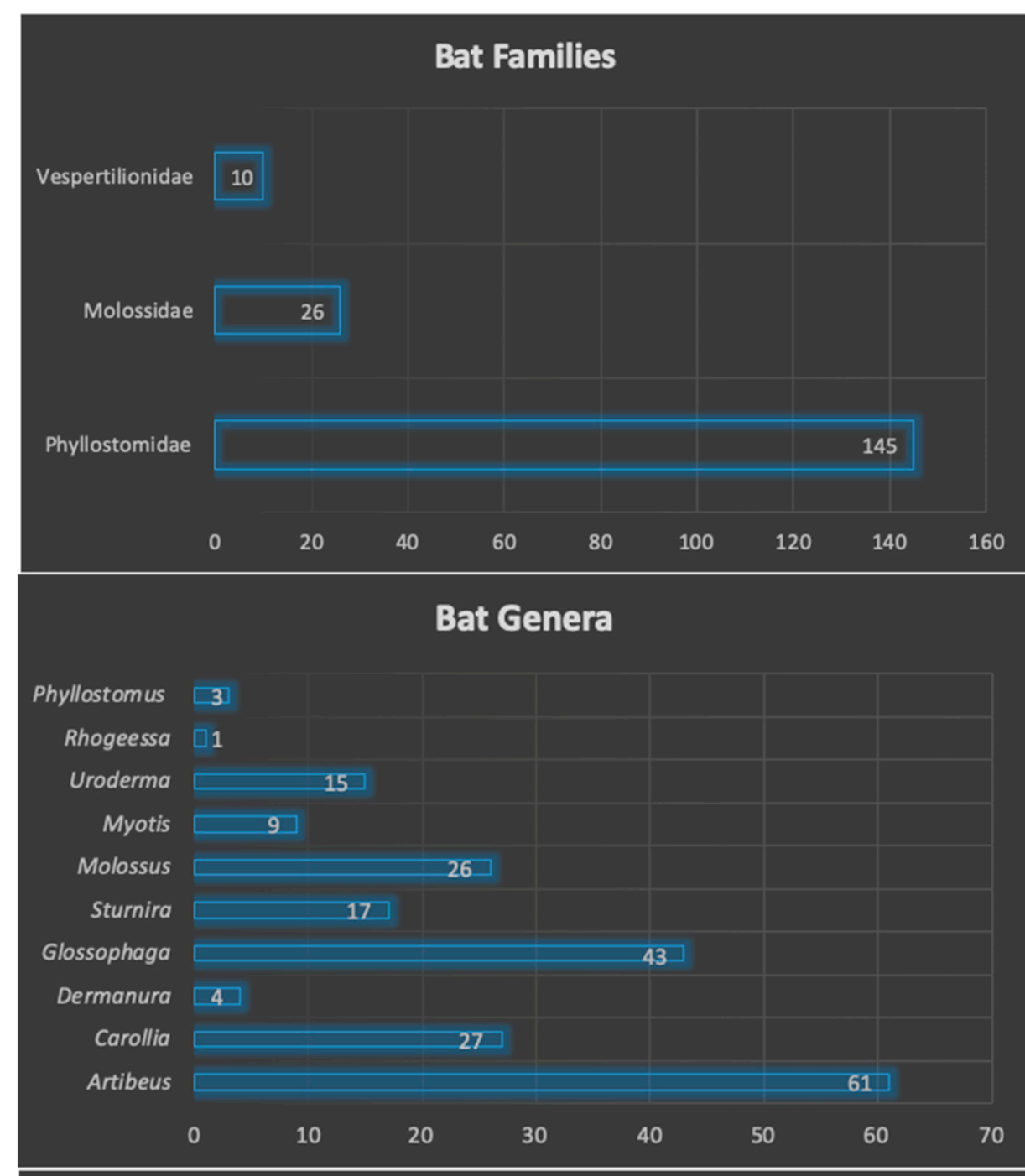

Bat species

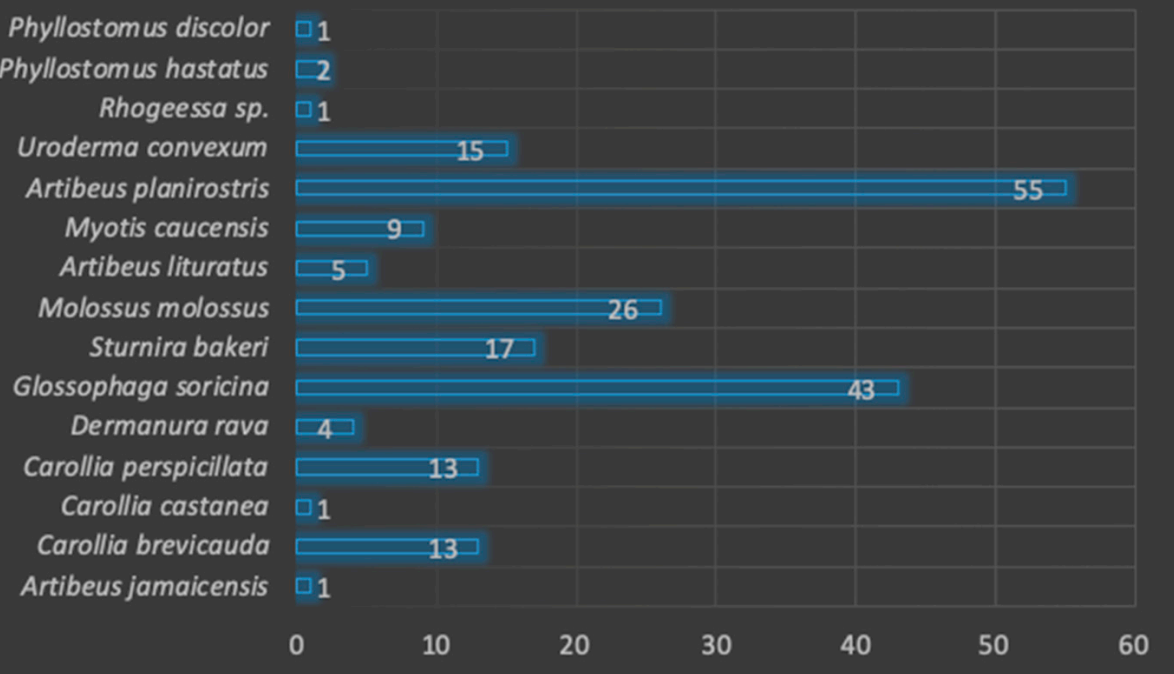

Figure 2. Diversity and abundance of bats captured in the five municipalities of the Urabá region. Figure 2 shows the 3 families, 10 genera, and 15 species of bats that were captured in the five sampling areas. The number of individuals for each taxonomic group classification are also indicated. 
Table 1. Diversity of bats captured in the study. This table shows information about the species, number, percentage, frequency and feeding habits of the 206 bats captured.

\begin{tabular}{|c|c|c|c|c|}
\hline Species & Number & Percentage (\%) & Frequency & Feeding Habits \\
\hline Artibeus jamaicensis & 1 & $0.49 \%$ & 0.005 & frugivore \\
\hline Carollia brevicauda & 13 & $6.31 \%$ & 0.063 & frugivore \\
\hline Carollia castanea & 1 & $0.49 \%$ & 0.005 & frugivore \\
\hline Carollia perspicillata & 13 & $6.31 \%$ & 0.063 & frugivore \\
\hline Dermanura rava & 4 & $1.94 \%$ & 0.019 & frugivore \\
\hline Glossophaga soricina & 43 & $20.87 \%$ & 0.209 & nectarivore \\
\hline Sturnira bakeri & 17 & $8.25 \%$ & 0.083 & frugivore \\
\hline Molossus molossus & 26 & $12.62 \%$ & 0.126 & insectivore \\
\hline Artibeus lituratus & 5 & $2.43 \%$ & 0.024 & frugivore \\
\hline Myotis caucensis & 9 & $4.37 \%$ & 0.044 & insectivore \\
\hline Artibeus planirostris & 55 & $26.70 \%$ & 0.267 & frugivore \\
\hline Uroderma convexum & 15 & $7.28 \%$ & 0.073 & frugivore \\
\hline Rhogeessa sp. & 1 & $0.49 \%$ & 0.005 & insectivore \\
\hline Phyllostomus hastatus & 2 & $0.97 \%$ & 0.010 & omnivore \\
\hline Phyllostomus discolor & 1 & $0.49 \%$ & 0.005 & omnivore \\
\hline TOTAL & 206 & $100 \%$ & 1 & \\
\hline
\end{tabular}

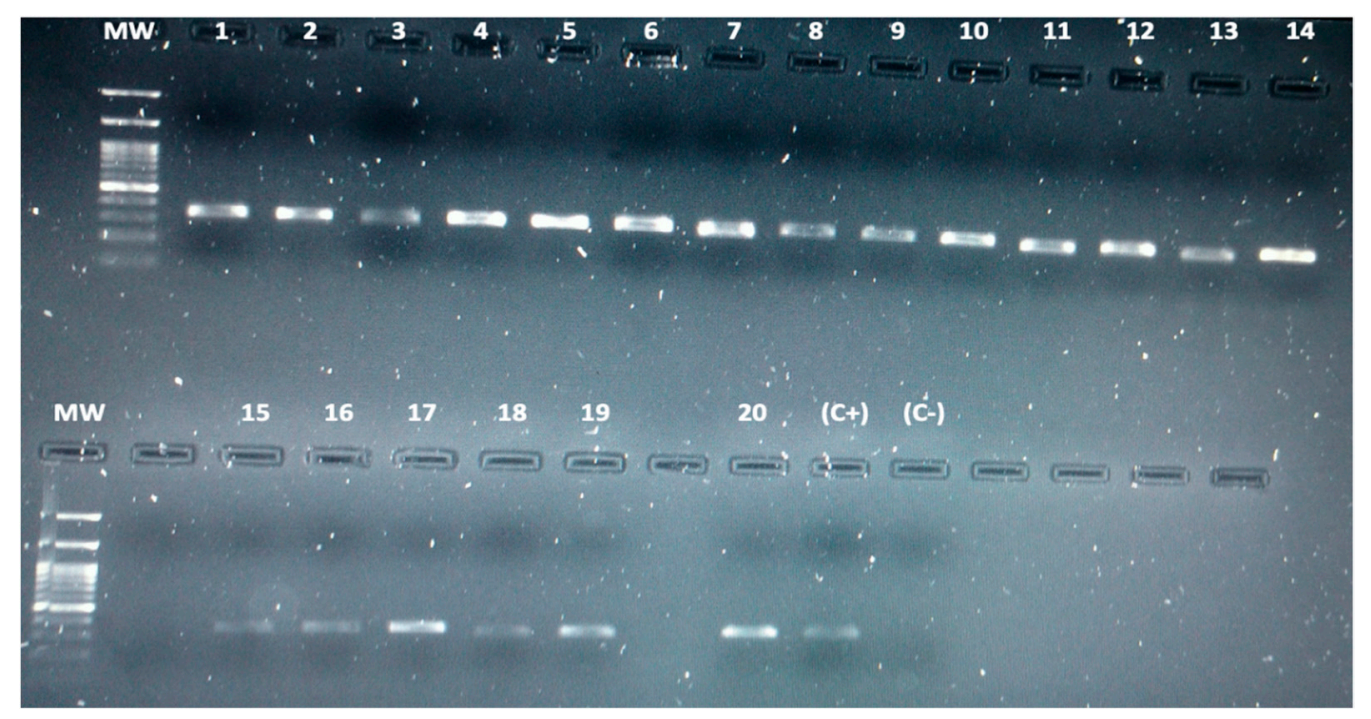

Figure 3. Molecular detection of bats naturally infected with Leptospira. The figure shows a 1\% agarose gel with the amplification products of 20 bats infected with Leptospira spp. The band (331 base pair) corresponding to a fragment of the $16 \mathrm{~S}$ ribosomal gene. A 100 base pair molecular weight markers were used. Additionally, a positive control ( $\mathrm{C}+$ : Leptospira interrogans) and a negative control (C-: PCR reagents without DNA) were used in all reactions.

Table 2. Natural infection of bats with different Leptospira species. This table shows the code of the positive samples, Leptospira species identified by amplification of the $16 \mathrm{~S}$ ribosomal gene, bat species infected, and the municipality from which the sampling area originated.

\begin{tabular}{|c|c|c|c|c|c|}
\hline Code & $\begin{array}{l}\text { Phylogenetic Identification } \\
\text { (16S Ribosomal Gene) }\end{array}$ & Infected Species & Feeding Habits & Gender & Municipality \\
\hline ZM-022 & Leptospira kirschneri & Carollia perspicillata & Frugivore & Female & Carepa \\
\hline ZM-025 & Leptospira kirschneri & Dermanura rava & Frugivore & Male & Carepa \\
\hline
\end{tabular}


Table 2. Cont.

\begin{tabular}{|c|c|c|c|c|c|}
\hline Code & $\begin{array}{l}\text { Phylogenetic Identification } \\
\text { (16S Ribosomal Gene) }\end{array}$ & Infected Species & Feeding Habits & Gender & Municipality \\
\hline ZM-047 & Leptospira interrogans & Glossophaga soricina & Nectarivore & Female & Apartadó \\
\hline ZM-056 & Leptospira kirschneri & Glossophaga soricina & Nectarivore & Male & Apartadó \\
\hline ZM-060 & Leptospira noguchii & Glossophaga soricina & Nectarivore & Female & Apartadó \\
\hline $\mathrm{ZN}-083$ & Leptospira noguchii & Uroderma convexum & Frugivore & Male & Chigorodó \\
\hline $\mathrm{ZN}-087$ & Leptospira noguchii & Uroderma convexum & Frugivore & Male & Chigorodó \\
\hline $\mathrm{ZN}-107$ & Leptospira noguchii & Uroderma convexum & Frugivore & Female & Chigorodó \\
\hline $\mathrm{ZN}-125$ & Leptospira noguchii & Molossus molossus & Insectivore & Female & Turbo \\
\hline ZN-126 & Leptospira kirschneri & Molossus molossus & Insectivore & Male & Turbo \\
\hline $\mathrm{ZN}-129$ & Leptospira kirschneri & Artibeus planirostris & Frugivore & Male & Turbo \\
\hline $\mathrm{ZN}-136$ & Leptospira borgpetersenii & Glossophaga soricina & Nectarivore & Female & Turbo \\
\hline ZN-138 & Leptospira borgpetersenii & Glossophaga soricina & Nectarivore & Female & Turbo \\
\hline ZN-139 & Leptospira interrogans & Artibeus planirostris & Frugivore & Male & Turbo \\
\hline $\mathrm{ZN}-141$ & Leptospira alexanderi & Uroderma convexum & Frugivore & Female & Turbo \\
\hline ZN-149 & Leptospira alexanderi & Glossophaga soricina & Nectarivore & Male & Turbo \\
\hline $\mathrm{ZN}-150$ & Leptospira borgpetersenii & Artibeus planirostris & Frugivore & Male & Turbo \\
\hline $\mathrm{ZN}-163$ & Leptospira kirschneri & Artibeus planirostris & Frugivore & Male & Turbo \\
\hline $\mathrm{ZN}-168$ & Leptospira noguchii & Uroderma convexum & Frugivore & Male & Necoclí \\
\hline ZN-169 & Leptospira interrogans & Uroderma convexum & Frugivore & Female & Necoclí \\
\hline
\end{tabular}

\subsection{Identification of Leptospira Species by Phylogenetic Analysis}

Through the amplification, sequencing, and phylogenetic analysis of the 20 positive bat samples, the following Leptospira species were identified: Leptospira borgpetersenii $(3 / 20-15 \%)$, Leptospira alexanderi (2/20-10\%), Leptospira noguchii (6/20-30\%), Leptospira interrogans (3/20-15\%), and Leptospira kirschneri (6/20-30\%). Results of the phylogenetic identification are shown in Figure 4.

\subsection{Host-Pathogen Relationship between Bats and Leptospira}

The host-pathogen association is as follows: Leptospira borgpetersenii infected 2 bats species (Glossophaga soricina and Artibeus planirostris), Leptospira alexanderi infected 2 bats species (Uroderma convexum and Glossophaga soricina), Leptospira noguchii infected 3 bats species (Glossophaga soricina, Uroderma convexum, and Molossus molossus), Leptospira interrogans infected 3 bats species (Glossophaga soricina, Artibeus planirostris, and Uroderma convexum) and Leptospira kirschneri infected 5 bats species (Carollia perspicillata, Dermanura rava, Glossophaga soricina, Molossus molossus, and Artibeus planirostris). The number of infected bats for each Leptospira species is shown in Table 3. Additionally, no renal infection was detected in 9 bat species (A. jamaicensis, C. brevicauda, C. castanea, S. bakeri, A. lituratus, M. caucensis, P. hastatus, P. discolor, and Rhogeessa sp.). 


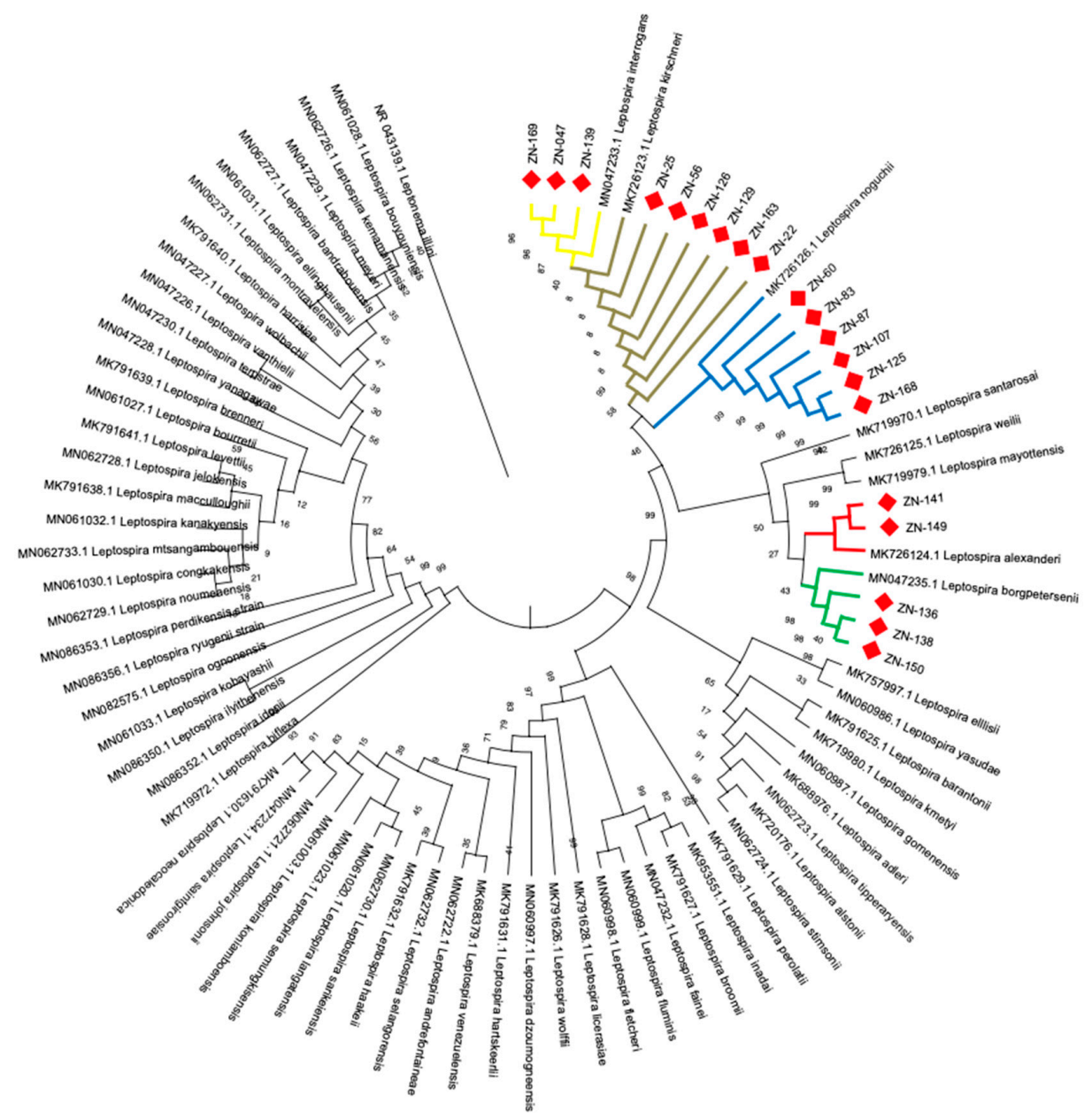

Figure 4. Identification of Leptospira species infecting bats by phylogenetic analysis of the $16 \mathrm{~S}$ ribosomal gene. Phylogenetic reconstruction of the $16 \mathrm{~S}$ ribosomal gene of the genus Leptospira is shown. Red diamonds represent the bats infected with Leptospira spp. in this study. Leptospira borgpetersenii, Leptospira alexanderi, Leptospira noguchii, Leptospira interrogans, and Leptospira kirschneri were the Leptospira species found infecting this bat population.

Table 3. Natural infection of bats with different Leptospira species. The table shows the host-pathogen relationship between 6 Leptospira species and 6 bats species susceptible to infection. The number of bats infected by each Leptospira species is shown in parentheses.

\begin{tabular}{ccc}
\hline Leptospira Species & Infected Bat Species & Infected Bats \\
\hline Leptospira borgpetersenii & Glossophaga soricina (2) & 3 \\
\hline Leptospira alexanderi & Artibeus planirostris (1) & 2 \\
\hline Leptospira noguchii & Uroderma convexum (1) & 6 \\
& Glossophaga soricina (1) & 3 \\
Leptospira interrogans & Uroderma convexum (4) & \\
& Molossus molossus (1) & \\
\hline Leptospira kirschneri & Glossophaga soricina (1) & \\
& Artibeus planirostris (1) & \\
& Uroderma convexum (1) & 6 \\
\hline
\end{tabular}




\section{Discussion}

Leptospirosis is a zoonotic disease that affects multiple animal reservoirs such as rodents [42], cattle [43], pigs [44], canines [45], capybaras [46], primates [47], turtles [48], sea lions [49], reptiles [50], bats [51], and other animals. Bats have gained great importance as efficient reservoirs and disseminators of Leptospira species for their biological attributes of hibernating [18], forming large colonies [19], migrating long distances [20], and having a long lifespan [21]. Although Neotropical bat species are not known to hibernate, that ability could favor the continuous maintenance of the bacteria in the host. Large colony formation facilitates transmission between different bats. Due to their ability to fly and migrate great distances, they could be an important bridge between urban, rural, and wild cycles of leptospirosis. Additionally, the longevity of bats could favor the dispersion of the bacteria through urine for prolonged periods of time into different environments and animals.

Worldwide, bats infected with Leptospira have been reported in at least 16 countries, with 50 different species of infected bats, and four Leptospira spp. as causative agents of the infection (L. interrogans, L. borgpetersenii, L. kirschneri, L. fainei) [22]. In Colombia the situation is no different, two studies reported bats infected with Leptospira. In the first study, 2 bats species (Eumops nanus, Lonchophylla fornicata) captured in schools belonging to the municipality of Sincelejo, Sucre, were found positive for Leptospira infection [39]. In the second study, 6 bats species (C. perspicillata, G. soricina, U. convexum, D. phaeotis, Desmodus rotundus, Lophostoma silvicola) deposited in the Museum of Natural History of the Pontificia Universidad Javeriana, in Bogotá, from dry forests of Córdoba department, were analyzed by PCR and their kidneys were positive for Leptospira infection [40]. Few studies have been conducted in Colombia; it is necessary to carry out the identification and characterization of infected bats with Leptospira in other regions of the country to decipher the biological role played by bats in the transmission cycle of leptospirosis in Colombia.

The objective of our investigation was to detect and identify Leptospira species infecting bats in the Antioquia Department. In the present study, 206 bats were captured, which were identified as belonging to 15 different species. The study found that $40 \%$ of bat species were infected with Leptospira, while $60 \%$ of the species were not infected. The three most abundant species were Artibeus planirostris (26.69\%), Glossophaga soricina (20.87\%), and Molossus molossus (12.62\%). In these most abundant species, at least one infected bat was found, suggesting a large number of infected bats at sampling sites. Interestingly, infected bats were also found in species with high, medium, and low abundance, which indicates that infection is independent of the abundance of bat populations. Also, 9 bats species of medium and low abundance were not infected, representing $60 \%$ of the species analyzed (A. jamaicensis, A. lituratus, C. brevicauda, C. castanea, S. bakeri, M. caucensis, P. hastatus, P. discolor, and Rhogeessa sp.) and $90.3 \%$ of the individuals analyzed (186/206). The absence of infection in these species may be due to the small number of individuals captured in the sampling process or a mechanism of natural resistance to infection by these bats.

Regarding feeding habits, the infected bats presented feeding habits such as insectivores, frugivores, and nectarivores; meanwhile, the uninfected bats presented eating habits such as frugivores, insectivores, and omnivores. Being omnivores the only difference between infected and uninfected bats, respectively. Another important finding in this study was the identification of five pathogenic Leptospira species infecting $40 \%$ of the species of captured bats (Leptospira borgpetersenii, Leptospira alexanderi, Leptospira noguchii, Leptospira interrogans, and Leptospira kirschneri). This result highlights the importance of bats as important reservoir hosts and disseminators of multiple pathogenic Leptospira species in the Urabá region (Antioquia-Colombia). It is important to highlight that $6 / 20$ infected bats correspond to Leptospira borgpetersenii and Leptospira noguchii, which emphasize the role of bats in maintaining these species of Leptospira in a wild. Additionally, these five Leptospira species are found in the P1 taxonomic group, which contains the most virulent of the human Leptospira species [4,5]. The infection rates for the different species were Leptospira borgpetersenii (3/20-15\%), Leptospira alexanderi (2/20-10\%), Leptospira noguchii $(6 / 20-30 \%)$, Leptospira interrogans (3/20-15\%), and Leptospira kirschneri $(6 / 20-30 \%)$. This is 
the first report in which these five pathogenic Leptospira species are identified infecting bats in the wild (Antioquia-Colombia). Additionally, these findings suggest the importance of bats in the dispersion and circulation of pathogenic Leptospira species into the environment. Given their ability to fly long distances, bats could serve as a bridge between wild and urban cycles of leptospirosis. Bats have been identified worldwide as an important reservoir of different Leptospira spp. (L. interrogans, L. borgpetersenii, L. kirschneri, L. fainei) [22]. In this study, Leptospira alexanderi and Leptospira noguchii are reported for the first time infecting bats. With respect to this host-pathogen relationship, it is noted that one species of Leptospira can infect multiple species of bats without being influenced by their feeding habits or population density, suggesting the presence of the bacteria in multiple environments.

The positive bats for Leptospira infection in the Urabá region correspond to six species in six genera and two families, Phyllostomidae and Molossidae. Almost all the phyllostomid bats are frugivorous, except for G. soricina, which is a nectarivorous species. Conversely, M. molossus is an insectivorous bat that feeds on small insects on the fly [52]. In contrast, C. perspicillata, A. planirostris, G. soricina, and U. convexum were relatively common in our netting effort; we found $M$. molossus in large numbers mostly because we netted close to their roosts near an old building. It appears that periurban areas where we netted still maintain a vegetation structure that allows these bat species to find roosting sites and food for their persistence [53-55], but also it enforces the fact that these species show high tolerance to landscape transformation (such as forest fragmentation [56]. Although two of these bats, G. soricine and M. molossus, have been found roosting nearby people's houses [57], direct interactions with people are rarely reported. Bats roosting in human spaces present risks because these are the places where bats conduct most of their activities, which may include deposition of urine and droppings that may carry the pathogen and contaminate water or food sources $[39,58]$.

In this study, we showed that bats in the Urabá region (Antioquia-Colombia) are important reservoirs and disseminators of pathogenic Leptospira species. With changing habitats due to man-made interventions, bats are becoming a significant reservoir of many zoonotic pathogens. These findings will help us in understanding the role played by bats in the infectious cycle of leptospirosis and help in the implementation of better prevention and control measures for leptospirosis in our country.

Author Contributions: Conceptualization; P.A.-F., F.P.M., S.S. and R.G.P.S.; methodology and investigation; S.S., F.P.M. and R.G.P.S., formal analysis; P.A.-F., F.P.M., S.S. and R.G.P.S.; resources; P.A.-F., J.Á.L., F.P.M. and R.G.P.S.; writing—original draft preparation; F.P.M. and R.G.P.S.; writing-review and editing; P.A.-F., S.S., F.P.M. and R.G.P.S.; visualization; P.A.-F., J.Á.L., F.P.M. and R.G.P.S. All authors have read and agreed to the published version of the manuscript.

Funding: This work was supported by MINCIENCIAS Colombia (Project: 122877757660—Infectious agents in bats: Contribution to the diagnosis of acute febrile syndrome of zoonotic origin in Urabá region (Antioquia-Colombia). Call for projects of Science, Technology and Innovation in Health—2017 (Call 777). FPM was a recipient of a US Scholar Fulbright Fellowship.

Institutional Review Board Statement: The study was conducted according to the guidelines of the Declaration of Helsinki, and approved by the Institutional Ethics Committee for animal experimentation of CES university in the Act 21 July 19-2016.

Informed Consent Statement: Not applicable.

Data Availability Statement: The genome sequences of the strains sequenced in this study have been deposited in GenBank under accession numbers MZ853085-MZ853104.

Acknowledgments: The authors are grateful for the support of the Basic Science Research Group (Graduates School-CES University), Department of Biological Sciences (Northern Arizona University-USA), Mammal Research Group and Centauro Research Group (University of Antioquia), and Minciencias-Colombia.

Conflicts of Interest: The authors declare no conflict of interests regarding the publication of this manuscript. 


\section{References}

1. Adler, B.; de la Peña Moctezuma, A. Leptospira and leptospirosis. Vet. Microbiol. 2010, 140, 287-296. [CrossRef] [PubMed]

2. Costa, F.; Hagan, J.; Calcagno, J.; Kane, M.; Torgerson, P.; Martinez-Silveira, M.S.; Stein, C.; Abela-Ridder, B.; Ko, A.I. Global morbidity and mortality of leptospirosis: A systematic review. PLoS Negl. Trop. Dis. 2015, 9, e0003898. [CrossRef]

3. Haake, D.A.; Levett, P.N. Leptospirosis in humans. Curr. Top. Microbiol. Immunol. 2015, 387, 65-97.

4. Vincent, A.T.; Schiettekatte, O.; Goarant, C.; Neel, V.K.; Bernet, E.; Thibeaux, R.; Ismail, N.; Khalid, M.K.N.M.; Amran, F.; Masuzawa, T.; et al. Revisiting the taxonomy and evolution of pathogenicity of the genus Leptospira through the prism of genomics. PLoS Negl. Trop. Dis. 2019, 13, e0007270. [CrossRef]

5. Cerqueira, G.M.; Picardeau, M. A century of Leptospira strain typing. Infect. Genet. Evol. 2009, 9, 760-768. [CrossRef]

6. Bello, S.; Rodríguez, M.; Paredes, A.; Mendivelso, F.; Walteros, D.; Rodríguez, F.; Realpe, M.E. Comportamiento de la vigilancia epidemiológica de la leptospirosis humana en Colombia, 2007-2011. Biomédica 2013, 33 (Suppl. 1), 153-160. [CrossRef]

7. Carreño, L.A.; Salas, D.; Beltrán, K.B. Prevalencia de leptospirosis en Colombia: Revisión sistemática de literatura. Prevalence of leptospirosis in Colombia: Systematic literature review. Rev. Salud Pública 2017, 19, 204-209. [CrossRef]

8. Agudelo, F.P.; Restrepo-Jaramillo, B.N.; Arboleda-Naranjo, M. Situación de la leptospirosis en el Urabá antioqueño colombiano: Estudio seroepidemiológico y factores de riesgo en población general urbana. Cad. Saúde Pública 2007, 23, 2094-2102. [CrossRef]

9. Sanchez, R.G.P.; Lopez, J.; Pereira, M.M.; Naranjo, M.A.; Agudelo-Flórez, P. Genetic diversity of Leptospira in northwestern Colombia: First report of Leptospira santarosai as a recognised leptospirosis agent. Mem. Inst. Oswaldo Cruz. 2016, 111, 737-744. [CrossRef] [PubMed]

10. Calisher, C.H.; Childs, J.E.; Field, H.E.; Holmes, K.V.; Schountz, T. Bats: Important reservoir hosts of emerging viruses. Clin. Microbiol. Rev. 2006, 19, 531-545. [CrossRef] [PubMed]

11. Mühldorfer, K. Bats and bacterial pathogens: A review. Zoonoses Public Health 2013, 60, 93-103. [CrossRef] [PubMed]

12. Juliane Schaer, J.; Perkins, S.L.; Decher, J.; Leendertz, F.H.; Fahr, J.; Weber, N.; Kai Matuschewski, K. High diversity of West African bat malaria parasites and a tight link with rodent Plasmodium taxa. Proc. Natl. Acad. Sci. USA 2013, 110, 17415-17419. [CrossRef]

13. Mok, W.Y.; Luizão, R.C.; Barreto da Silva, M.S. Isolation of fungi from bats of the Amazon basin. Appl. Environ. Microbiol. 1982, 44, 570-575. [CrossRef] [PubMed]

14. Griffin, D.R. Migrations and homing in bats. In Biology of Bats, 2nd ed.; Wimsatt, W.A., Ed.; Academic Press: New York, NY, USA, 1970; pp. 233-264.

15. Amador, L.I.; Moyers-Arévalo, R.L.; Almeida, F.C.; Catalano, S.A.; Giannini, N.P. Bat systematics in the light of unconstrained analyses of a comprehensive molecular supermatrix. J. Mammal. Evol. 2018, 25, 37-70. [CrossRef]

16. Teeling, E.C.; Springer, M.S.; Madsen, O.; Bates, P.; O’Brien, S.J.; Murphy, W.J. A molecular phylogeny for bats illuminates biogeography and the fossil record. Science 2005, 307, 580-584. [CrossRef]

17. Holland, R.A.; Waters, D.A.; Rayner, J.M. Echolocation signal structure in the megachiropteran bat Rousettus aegyptiacus Geoffroy 1810. J. Exp. Biol. 2004, 207, 4361-4369. [CrossRef] [PubMed]

18. Lyman, C.P. Thermoregulation and metabolism in bats. In Biology of Bats, 2nd ed.; Wimsatt, W.A., Ed.; Academic Press: New York, NY, USA, 1970; pp. 301-330.

19. Constantine, D.G. Activity Patterns of the Mexican Free-Tailed Bat; University of New Mexico Press: Albuquerque, NM, USA, 1967; pp. 1-79.

20. Cockrum, E.L. Migration in the Guano Bat, Tadarida Brasiliensis; University of Kansas Museum of Natural History: Lawrence, KS, USA, 1969; pp. 303-336.

21. Eisenberg, J.F. The density and biomass of tropical mammals. In Conservation Biology; Soule, M., Wilcox, B.A., Eds.; Sinauer Associates: Sunderland, MA, USA, 1980; pp. 35-56.

22. Dietrich, M.; Mühldorfer, K.; Tortosa, P.; Markotter, W. Leptospira and bats: Story of an emerging friendship. PLOS Pathog. 2015, 11, e1005176. [CrossRef]

23. Bunnell, J.E.; Hice, C.L.; Watts, D.M.; Montrueil, V.; Tesh, R.B.; Vinetz, J.M. Detection of pathogenic Leptospira spp. infections among mammals captured in the Peruvian Amazon basin region. Am. J. Trop. Med. Hyg. 2000, 63, 255-258. [CrossRef] [PubMed]

24. Zetun, C.; Hoffmann, J.; Silva, R.; Souza, L.; Langoni, H. Leptospira spp. and Toxoplasma gondii antibodies in vampire bats (Desmodus rotundus) in Botucatu region, Brazil. J. Venom. Anim. Toxins Incl. Trop. Dis. 2009, 15, 546-552. [CrossRef]

25. Ramirez, N.N.; Alegre, E.A.; De Biasio, M.B.; Bastiani, C.E. Detecciósn de leptospiras patógenas en tejido renal de murciélagos de Corrientes, Argentina. Rev. Vet. 2014, 25, 16-20. [CrossRef]

26. Smythe, L.D.; Field, H.E.; Barnett, L.; Smith, C.S.; Sohnt, M.F.; Moore, M.R.; Rolfe, P.F. Leptospiral antibodies in flying foxes in Australia. J. Wildl. Dis. 2002, 38, 182-186. [CrossRef] [PubMed]

27. Lagadec, E.; Gomard, Y.; Guernier, V.; Dietrich, M.; Pascalis, H.; Symonds, M.L.; Moore, M.R.; Rolfe, P.F. Pathogenic Leptospira spp. in bats, Madagascar and Union of the Comoros. Emerg. Infect. Dis. 2021, 18, 1696-1698. [CrossRef]

28. Desvars, A.; Naze, F.; Benneveau, A.; Cardinale, E.; Michault, A. Endemicity of leptospirosis in domestic and wild animal species from Reunion Island (Indian Ocean). Epidemiol. Infect. 2013, 141, 1154-1165. [CrossRef]

29. Desvars, A.; Naze, F.; Vourc'h, G.; Cardinale, E.; Picardeau, M.; Bourhy, P. Similarities in Leptospira serogroup and species distribution in animals and humans in the Indian ocean island of Mayotte. Am. J. Trop. Med. Hyg. 2021, 87, 134-140. [CrossRef] 
30. Van Peenen, P.F.D.; Light, R.H.; Sulianti-Saroso, J. Leptospirosis in wild mammals of Indonesia-Recent surveys. Southeast Asian J. Trop. Med. Public Health 1971, 2, 496-502. [PubMed]

31. Thayaparan, S.; Robertson, I.A.N.; Amraan, F.; Ut, L.S.U.; Abdullah, M.T. Serological prevalence of leptospiral Infection in wildlife in Sarawak, Malaysia. Borneo J. Res. Sci. Technol. 2013, 2, 71-74. [CrossRef]

32. Mgode, G.F.; Mbugi, H.A.; Mhamphi, G.G.; Ndanga, D.; Nkwama, E.L. Seroprevalence of Leptospira infection in bats roosting in human settlements in Morogoro municipality in Tanzania. Tanzan. J. Health Res. 2014, 16, 1-7. [CrossRef] [PubMed]

33. Everard, C.R.; Fraser-Chanpong, G.M.; Bhagwandin, L.J.; Race, M.W.; James, A.C. Leptospires in wildlife from Trinidad and Grenada. J. Wildl. Dis. 1983, 19, 192-199. [CrossRef] [PubMed]

34. Sebek, Z.; Sixl, W.; Reinthaler, F.; Valova, M.; Scneeweiss, W.; Stünzner, D.; Mascher, F. Results of serological examination for leptospirosis of domestic and wild animals in the Upper Nile province (Sudan). J. Hyg. Epidemiol. Microb. Immunol. 1989, 33, 337-345.

35. Ogawa, H.; Koizumi, N.; Ohnuma, A.; Mutemwa, A.; Hang, B.M.; Mweene, A.S.; Takada, A.; Sugimoto, C.; Suzuki, Y.; Kida, H.; et al. Molecular epidemiology of pathogenic Leptospira spp. in the straw-colored fruit bat (Eidolon helvum) migrating to Zambia from the Democratic Republic of Congo. Infect. Genet. Evol. 2015, 32, 143-147. [CrossRef] [PubMed]

36. Jobbins, S.E.; Alexander, K.A. Evidence of Leptospira sp. infection among a diversity of African wildlife species: Beyond the usual suspects. Trans. R. Soc. Trop. Med. Hyg. 2015, 109, 349-351. [CrossRef] [PubMed]

37. Tagi-Zade, T.A.; Mardanly, A.S.; Akhmedov, I.B.; Alekperov, F.P.; Gasanov, S.N. Examination of bats for leptospirosis in the territory of Azerbaijan SSR. Zhurnal Mikrobiol. Epidemiol. I Immunobiol. 1970, 9, 118-121.

38. Victoria, R.J.; Iriarte, L.J.; Sampedro, A.C. Presence of Leptospira spp. in urban bats from Sincelejo, Sucre, Colombia. Int. J. Pharm. Tech. Res. 2018, 11, 218-225.

39. Mateus, J.; Gómez, N.; Herrera-Sepúlveda, M.T.; Hidalgo, M.; Pérez-Torres, J.; Cuervo, C. Bats are a potential reservoir of pathogenic Leptospira species in Colombia. J. Infect. Dev. Ctries. 2019, 13, 278-283. [CrossRef]

40. Díaz, M.M.; Solari, S.; Aguirre, L.F.; Aguiar, L.M.S.; Barquez, R.M. Clave de identificación de los murciélagos de Sudamérica/Chave de identificação dos morcegos da América do Sul. Publ. Espec. Nro 2016, 2, 160.

41. Peláez Sánchez, R.G.; Quintero, J.Á.L.; Pereira, M.M.; Agudelo-Flórez, P. High-resolution melting curve analysis of the 16S ribosomal gene to detect and identify pathogenic and saprophytic Leptospira species in colombian isolates. Am. J. Trop. Med. Hyg. 2017, 96, 1031-1038. [CrossRef] [PubMed]

42. Boey, K.; Shiokawa, K.; Rajeev, S. Leptospira infection in rats: A literature review of global prevalence and distribution. PLoS Negl. Trop. Dis. 2019, 13, e0007499. [CrossRef]

43. Talpada, M.D.; Garvey, N.; Sprowls, R.; Eugster, A.K.; Vinetz, J.M. Prevalence of leptospiral infection in Texas Cattle: Implications for transmission to humans. Vector Borne Zoonotic Dis. 2003, 3, 141-147. [CrossRef]

44. Calderón, A.; Rodríguez, V.; Máttar, S.; Arrieta, G. Leptospirosis in pigs, dogs, rodents, humans, and water in an area of the Colombian tropics. Trop. Anim. Health Prod. 2014, 46, 427-432. [CrossRef] [PubMed]

45. Alton, G.D.; Berke, O.; Reid-Smith, R.; Ojkic, D.; Prescott, J.F. Increase in seroprevalence of canine leptospirosis and its risk factors, Ontario 1998-2006. Can. J. Vet. Res. 2009, 73, 167-175.

46. Jorge, S.; Monte, L.G.; Coimbra, M.A.; Albano, A.P.; Hartwig, D.D.; Lucas, C.; Seixas, F.K.; Dellagostin, O.A.; Hartleben, C.P. Detection of virulence factors and molecular typing of pathogenic Leptospira from capybara (Hydrochaeris hydrochaeris). Curr. Microbiol. 2012, 65, 461-464. [CrossRef]

47. Szonyi, B.; Agudelo-Flórez, P.; Ramírez, M.; Moreno, N.; Ko, A.I. An outbreak of severe leptospirosis in capuchin (Cebus) monkeys. Vet. J. 2011, 188, 237-239. [CrossRef]

48. Dezzutto, D.; Barbero, R.; Canale, G.; Acutis, P.L.; Biolatti, C.; Dogliero, A.; Mitzy, M.D.; Francone, P.; Colzani, A.; Bergagna, S.; et al. Detection of Leptospira spp. in water turtle (trachemys scripta) living in ponds of Urban Parks. Vet. Sci. 2017, 4, 51. [CrossRef] [PubMed]

49. Colagross-Schouten, A.M.; Mazet, J.A.; Gulland, F.M.; Miller, M.A.; Hietala, S. Diagnosis and seroprevalence of leptospirosis in California sea lions from coastal California. J. Wildl. Dis. 2002, 38, 7-17. [CrossRef] [PubMed]

50. Lindtner-Knific, R.; Vergles-Rataj, A.; Vlahović, K.; Zrimšek, P.; Dovč, A. Prevalence of antibodies against Leptospira sp. in snakes, lizards and turtles in Slovenia. Acta Vet. Scand. 2013, 55, 65. [CrossRef] [PubMed]

51. Bessa, T.A.F.; Spichler, A.; Chapola, E.G.B.; Husch, A.C.; de Almeida, M.F.; Husch, A.C. The contribution of bats to leptospirosis transmission in Sao Paulo City, Brazil. Am. J. Trop. Med. Hyg. 2010, 82, 315-317. [CrossRef]

52. Ramírez-Mejía, A.F.; Urbina-Cardona, J.N.; Sánchez, F. Functional diversity of phyllostomid bats in an urban-rural landscape: A scale-dependent analysis. Biotropica 2020, 52, 1168-1182. [CrossRef]

53. Jung, K.; Kalko, E.K. Adaptability and vulnerability of high flying Neotropical aerial insectivorous bats to urbanization. Divers. Distrib. 2011, 17, 262-274. [CrossRef]

54. Russo, D.; Ancillotto, L. Sensitivity of bats to urbanization: A review. Mamm. Biol. 2015, 80, 205-212. [CrossRef]

55. Kalko, E.K.; Handley, C.O.; Handley, D. Organization, diversity, and long-term dynamics of a Neotropical bat community. In Long-Term Studies of Vertebrate Communities; Cody, M.L., Smallwood, J.A., Eds.; Academic Press: New York, NY, USA, 1996; pp. 503-553. 
56. Meyer, C.F.J.; Struebig, M.J.; Willig, M.R. Responses of tropical bats to habitat fragmentation, logging, and deforestation. In Bats in the Anthropocene: Conservation of Bats in a Changing World; Voigt, C., Kingston, T., Eds.; Springer: Cham, Switzerland, 2016; pp. 63-103.

57. Tamsitt, J.R.; Valdivieso, D. Los murciélagos y la salud pública: Estudio con especial referencia a Puerto Rico. Boletín Oficina Sanit. Panam. 1970, 69, 122-140.

58. Drews, C. Convivencia con murciélagos de Costa Rica. Ambientico 2002, 103, 12-13. 